\title{
Impact of periprocedural myocardial necrosis on short term clinical outcome
}

\author{
M Hamdi', Y Hagag, M Khaled, A Elhadidy \\ From ESICM LIVES 2015 \\ Berlin, Germany. 3-7 October 2015
}

\section{Objectives}

To assess the prognostic value of periprocedural myocardial injury during elective in the early post intervention period.

\section{Background}

Elevations in the biochemical markers of myocardial damage are frequently detected after percutaneous coronary revascularization, but their clinical significance is still uncertain.

\section{Methods}

$\mathrm{CK}, \mathrm{CK}-\mathrm{MB}$, and cTn I were prospectively assessed in 100 patients who underwent elective PCI during the period between Jan 2012 and Jan 2013.

Patients were subjected to history taking, routine laboratory investigations, electrocardiogram ( ECG), cardiac biomarkers assay, and Echocardiography pre and post PCI.

The primary end point was death, myocardial infarction or severe, recurrent ischemia at 90 days.

\section{Results}

Overall, 30 patients (30\%) had elevated cardiac biomarkers after PCI. Elevated cardiac biomarkers were associated with significantly higher risks of the primary end point (MACE) in the early post intervention period (43.3\% vs. $12.9 \%$; $\mathrm{p}<0.001)$ and a significantly higher risk of 3 months follow up MACE (66.7\% vs. $14.3 \%$; p < 0.001).

Elevation of cardiac biomarkers is more likely in older patients ( $\left.p_{-} 0.034\right)$, diabetics $(96.7 \%$ vs. $11.4 \%$; $\mathrm{p}<$ $0.001)$. , those with history of old $\mathrm{MI}(76.7 \%$ vs. $11.4 \%$; $\mathrm{p}<0.001)$, and patients who had CHF ( $30 \%$ vs. $4.3 \%$; $\mathrm{p}<0.001)$.while the gender, previous history of CVS,

Cairo University, Cairo, Egypt

(c) 2015 Hamdi et al.; This is an Open Access article distributed under the terms of the Creative Commons Attribution License (http:// creativecommons.org/licenses/by/4.0), which permits unrestricted use, distribution, and reproduction in any medium, provided the original work is properly cited.
COPD, and liver cirrhosis were non significant predictors of elevated cardiac biomarkers.

\section{Conclusions}

Elevated cardiac biomarkers, often observed after elective PCI in patients with IHD, is associated with worse early post intervention and 90-day clinical outcomes. This marker, therefore, is a useful prognostic indicator in such patients.

Published: 1 October 2015

doi:10.1186/2197-425X-3-S1-A954

Cite this article as: Hamdi et al:: Impact of periprocedural myocardial

necrosis on short term clinical outcome. Intensive Care Medicine

Experimental 2015 3(Suppl 1):A954.

\section{Submit your manuscript to a SpringerOpen ${ }^{\circ}$ journal and benefit from: \\ - Convenient online submission \\ - Rigorous peer review \\ - Immediate publication on acceptance \\ - Open access: articles freely available online \\ - High visibility within the field \\ Retaining the copyright to your article}

Submit your next manuscript at $>$ springeropen.com 